\title{
Differences between learning model of inquiry and direct instruction toward learning outcomes on discus throw
}

\author{
Andrew Rinaldi Sinulingga ${ }^{1, *}$ (1) Deny Pradana Saputro ${ }^{1 \oplus}$, \\ Andi Nova ${ }^{2}$ \\ Universitas Riau, Indonesia ${ }^{1}$ \\ Universitas Samudra, Indonesia ${ }^{2}$
}

Received: 19 April 2020; Accepted 10 December 2020; Published 05 January 2021

Ed 2021; 6(1): 15-21

\begin{abstract}
Determining the learning model in teaching and learning activities will help students succeed, especially in physical education lessons. A Teacher is demanded to choose the right learning model according to the needs field need suitable for a pupil's characteristic. This research aims to find out determine differences between the learning model of inquiry and direct instruction on learning outcomes of discus throw. The subject of the study is students of grade ninth in State Junior High School three Pekanbaru. The research method is an experiment in which each group is fifteen students in inquiry learning models and indirect instruction models. The in research was $t$, the instrument discus throw, which consists of holding the discus, approaching, throwing, and following through. The T-test is an analysis technique of the data in this study by presenting two different learning groups. The result of the use of products learning outcomes of discus throwing on students of grade ninth at state junior high school three Pekanbaru by implementing inquiry learning models and direct instruction in learning of discus throw. The inquiry learning model in this study showed better results than direct instruction. The gain of students' average value contributed 13.5, whereas the average value of students in direct instruction was 12.0. Therefore, it can be concluded that the inquiry learning model is better to be implemented for the learning of physical education, especially on discus throw lesson than the implementation of direct instruction in State Junior High School three Pekanbaru.
\end{abstract}

Keywords: Inquiry learning model; direct learning model; discuss throw

https://doi.org/10.25299/sportarea.2021.vol6(1).4856

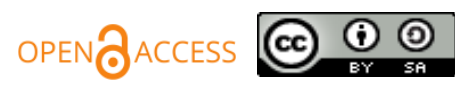

Copyright @ 2021 Andrew Rinaldi Sinulingga, Deny Pradana Saputro, Andi Nova

Corresponding author: Andrew Rinaldi Sinulingga, Physical Education Health and Recreation, Universitas Riau, Pekanbaru, Riau, Indonesia

Email: andrew.rinaldi@lecturer.unri.ac.id

How To Cite: Sinulingga, A. R., \& Saputro, D. P., \& Nova, A. (2021). Differences between learning model of inquiry and direct instruction toward learning outcomes on discus throw. Journal Sport Area, 6(1), 15-21. https://doi.org/10.25299/sportarea.2021.vol6(1).4856

\section{INTRODUCTION}

Helping people become intelligent beings, smart and useful, is the excellent purpose of education (Sudrajat, 2011). Education is not only about how to make children have good intellectual abilities. More than that, building and forming students with exemplary character and upholding moral and spiritual values are also the role of education (Annas, 2017). The character education is packaged in a curriculum from now on, pinned on each of the subjects assigned to each education level. A good education was the education of children of age early at primary, junior secondary, secondary, and higher education. As one of the subjects 
in the curriculum, physical education also has a role in realizing the education plans that have been embedded in the curriculum, especially curriculum year 2013 nowadays.

The curriculum of education can not be separated from physical education subjects are arguably the only lesson that has physical activity. Physical education in its Implementation develops motor skills for the benefit of fitness and health. It hones knowledge to think in the process of problem-solving, learn various attitudes through games, and apply a healthy lifestyle (Kurniawan, 2014). Referring to the quote, it means that all of the elements responsible for both the school and outside the school, like a leader, educators, and students, create an effective learning environment and the achievement of learning indicators. Students and teachers who are directly involved in the field must create a learning atmosphere that achieves the indicator objectives of each sub-subject matter being studied. However, the need for cooperation between teachers and students, but who still plays an active role teacher to know each student's characteristics, so that applied fits the atmosphere of the field and acceptable and followed by students with learning results both individually and cumulatively. Almost similar to the findings conveyed by Wahyuni (2015) in her research, teachers have an essential role in shaping students' character because teachers are the ones who most determine the success or failure of the learning process and character education. This is also reinforced by the contention Ajepri (2016) in her research that teachers have an essential role in shaping students' character because teachers are the ones who most determine the success or failure of the learning process and character education. The contention also reinforces this.

They are talking about physical education. In general, physical education studies various forms of sports by integrating different kinds of motor movements to form effective and efficient campaigns for each sport. However, there is something that needs to be remembered, that learning sports through physical education, which is carried out in schools, does not necessarily only learn about motor movements, more than that there are many aspects that need to be developed to be able to form Indonesian children who are physically and mentally healthy. Teacher of physical education has a significant role in facilitating the physical education learning activities considering one of the sub-subject matters displayed on the junior high school athletics in the ninth grade is the number of throwing that does not belong in sports games. In the number of throwing, students learn the basic techniques of throwing the discus.

The curriculum in 2013 on a lesson plan stated that the purpose of essential competencies 4.3 is practicing variations and combinations of the basic techniques in athletics (race walking, running, jumping, and throwing) by smoothing, controlling, and coordinating. As for the indicators in the discus throwing subject matter, students are required to be able to explain and practice a combination of discus throwing techniques. In the basic technique of throwing discus, several techniques must be mastered, starting from holding the disc, approaching before throwing, twisting the body when releasing the disc, and further movements after the disc are removed from the hand (Aji, Soegiyanto, \& Rahayu, 2015). This throwing number can be a subject matter that is difficult for students to implement because it requires movement skills and capable of understanding to create a perfect movement, especially during transitions when the disc is released from the hand.

Referring to the experiences and observations by authors at Junior High School 3, Pekanbaru obtained data from the study discus by presenting the 16 descriptors of holding the disc (4 descriptors), approach (4 descriptors), throwing (4 descriptors). In the followthrough on movement (4 descriptors), the average student gets a score of 10.5 from the total score of 30 students, namely 315 . This problem is caused by the diversity of student skill levels and the lack of insight from educators in choosing the proper learning model on this subject matter. The application of several variations of various learning models with different concepts is more useful for increasing abilities in the cognitive, affective, and psychomotor categories (Gustiawati \& Stafei, 2015).

Furthermore, the implementation of the correct learning model instruction will create a good interaction characterized by student interest to achieve the minimum completeness set by the school (Novion, 2018). The learning model has described the activities from the beginning to the end, accompanied by approaches, methods, strategies, techniques that students use to achieve learning objectives. 
Previous research conducted by former researchers Sinulingga and Nova (2018) regarding the impression between teaching models and motivation in long jump learning outcomes, it was concluded that there was a significant impact between the teaching models presented along with the reason for the long jump learning success in junior high school students. Followed by Fitriani (2016) research, there was progress in elementary school four students' skills in throwing and catching ball subject matter by applying the inquiry learning model. In connection with previous research, the researcher intends to explore the importance of applying learning models to learning outcomes, especially in the sub-subject matter of throwing, namely the combination of skills using tools. The researcher wants to present two contradictory learning models, the students' learning outcomes of throwing discus by applying (1) the inquiry learning model, and (2) the direct learning model. Researchers assume that this study's result has a significant value related to improving the quality and competence of students in physical education lessons in discus throwing subject matter.

\section{METHODS}

State Junior High School three Pekanbaru is the place where the research was carried out. Implementation in the field is carried out twice for treatment, which refers to the lesson plan. For the Implementation of the pre-test and the final test, it is carried out every one hour of the meeting referring to the K-13 curriculum that the Physical Education, Sports, and Health lessons for 3 JP mean 3 x 45 minutes. 158-grade ninth students of junior high three Pekanbaru for the 2019/2020 academic year, which are spread over five classes, are the population of this study. Samples of this research were 30 students with a piece carried out conditionally for a specially selected example with certain criteria (Sudayana, 2015). This type of research is experimental. The description in this study is Randomized Pretest - Posttest Design as below:

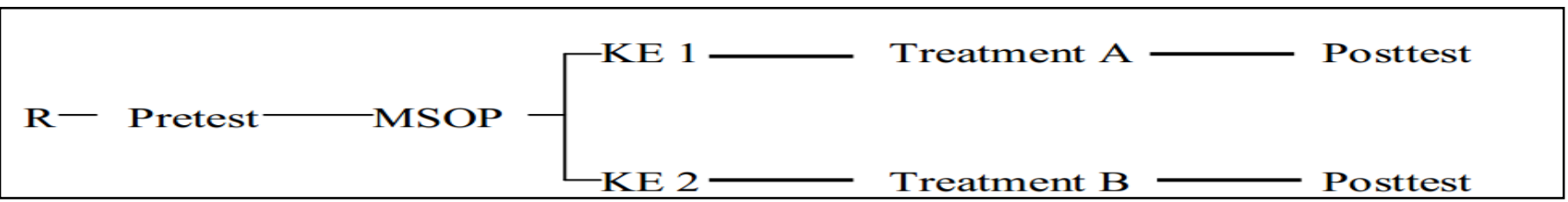

Fig. 1 Randomized Pretest-Postest Design

(Sudayana, 2015)

\section{Information:}

$\mathrm{R}=$ Random

Pre-Test $\quad=$ Initial test of throwing the discus

MSOP $\quad=$ Matched Subject Ordinal Pairing

$\mathrm{KE} 1=$ Experimental group 1

KE $2 \quad$ Experimental group 2

Treatment A = Discus execution applies the Inquiry model

Treatment B = Implementation of throwing the disc using the Direct model

Post-Test $\quad=$ Final test

The division of groups for sample placement into two learning models refers to the initial test results. First, the samples are sorted from top to bottom. Then the samples were placed alternately into the two groups of learning models presented. For more information, see table 1 .

Table. 1 Distribution Data in Each Group

\begin{tabular}{ccc}
\hline Group 1 & Group 2 \\
\hline 1 & 2 \\
3 & 4 \\
5 & So on \\
\hline
\end{tabular}

(Sudayana, 2015) 
In this study, data will be generated from the results of the discus throwing exam, using an assessment rubric that has been compiled from various relevant theories starting from holding the disc to the advanced stage after realizing discus (Jarver, 2014), and supported by previous research conducted by previous researchers (Sinulingga, 2018).

Table 2. Sheet Assessment of Learning Outcome in Discus Throw

\begin{tabular}{|c|c|c|}
\hline Indicator & Decryptor & Score \\
\hline Holding Discus & $\begin{array}{l}\text { 1. The disc is placed on the palm } \\
\text { 2. The fingers are spread across the edges of the disc } \\
\text { 3. The first of the } 4 \text { fingers that hold the disc } \\
\text { 4. The disc does not drop when the palm is directed downward }\end{array}$ & $\begin{array}{l}\text { The teacher gives a check-list of } \\
\text { each descriptor by the student } \\
\text { with a score of } \max =4\end{array}$ \\
\hline Prefix/Approach & $\begin{array}{l}\text { 1. Stand with your back to the track field } \\
\text { 2. Position of the hand holding the disc towards the back of the } \\
\text { body } \\
\text { 3. The left leg is bent } \\
\text { 4. Swing } 2-3 \text { disc before turning }\end{array}$ & $\begin{array}{l}\text { The teacher gives a check-list of } \\
\text { each descriptor by the student } \\
\text { with a score of } \max =4\end{array}$ \\
\hline Throwing Discus & $\begin{array}{l}\text { 1. Turn your forelegs and head first } \\
\text { 2. Shoulders point completely forward of the track } \\
\text { 3. The disc starts to release when the right foot hits the ground } \\
\text { 4. The disc is removed at shoulder level/parallel }\end{array}$ & $\begin{array}{l}\text { The teacher gives a check-list of } \\
\text { each descriptor by the student } \\
\text { with a score of } \max =4\end{array}$ \\
\hline Follow through Motion & $\begin{array}{l}\text { 1. As quick as possible left foot touching the ground } \\
\text { 2. Moving weight to the left foot } \\
\text { 3. Nobody parts is out from the track } \\
\text { 4. Stay in the balance after the throwing motion }\end{array}$ & $\begin{array}{l}\text { The teacher gives a check-list of } \\
\text { each descriptor by the student } \\
\text { with a score of } \max =4\end{array}$ \\
\hline
\end{tabular}

(Jarver, 2014)

The stages of collecting the scores are described as follows: (1) there is code "get ready," the student stands in a sideways circle facing the throw direction. The student shows how the attitude is in holding the disc, (2) there is a code for "ready" the student takes a prefix attitude, (3) there is a code for "yes" the student starts to take a square, then throws it and is followed by the final movement when the disc is released from the hand, (4) Each student has the opportunity as many as three times for taking the best results. The throw is declared a failure when; (1) positioning the foot's thrower out of the zone specified area, (2) the result throwing is not on a predetermined sector site.

The stages of the analytical test applied to data processing are as follows: (a) Normality test using the Liliefors test, (b) homogeneity test, (c) t-test in the same and different sample groups (Sudayana, 2015). The value of increase was obtained after all samples received treatment, then distributed between the mean different by pre-test and then multiplied by $100 \%$ where the mean-difference was obtained from the mean post-test minus the pre-test mean (Nelson \& Thomas, 1990).

\section{RESULTS AND DISCUSSIONS}

After carrying out discus throwing learning with the presentation of two different study groups, then continued with the final test of discus throwing learning outcomes, the following data were obtained regarding the application of the inquiry learning model and the direct model in grade ninth students of the Junior High School 3 Pekanbaru as follows:

Table 3. Results of T-Test for Each Group and Between Groups

\begin{tabular}{lccc}
\multicolumn{1}{c}{ Group } & $\mathbf{t}_{\text {count }}$ & $\mathbf{t}_{\text {table } \mathbf{0 . 0 5}}$ & \multicolumn{1}{c}{ Information } \\
\hline Pre-Test & 0.26653 & 1.70113 & Not significant \\
\hline Group X pre-test and final test $_{2}$ pre-test and final test & 4.43655 & 1,77093 & Significant \\
\hline Group X & 2.45496 & 1,77093 & Significant \\
\hline Post-Test & 2,023765 & 1.70113 & Significant \\
\hline
\end{tabular}


The first analysis is the initial test of the inquiry learning model group and the direct model. The inquiry learning model and the direct learning model have a value of 0.26653 , which is smaller than the t-table with a value of 1.70113. With the calculation using the t-test, in this case, it is concluded that there is no significant difference between the initial test results of the learning throwing disc between the study groups. In this case, in the initial test, there was no treatment given to the sample.

The results of the pre-test and post-test in the inquiry learning model group. After the inquiry study group obtained action, the next stage was to look at the results that occurred in the sample by performing statistical calculations using the t-test formula. The t-test is worth 4.43655 from the calculation results between the initial test and the final test, greater than the $t_{\text {table }}$ worth 1.77093 , rejecting the null hypothesis. So that the conclusion is obtained that the Implementation of the inquiry learning model has a better impact on discus throwing learning and statistically obtained a value of $25.78 \%$ of the results of student learning improvement in discus throwing subject matter, this is in line with Juliantine (2009) states that the increase in students' cognitive level abilities can be done by applying the inquiry learning model, in addition to increasing skills in the psychomotor field to make students more expressive and creative.

The results of the test learning from throw the disc in the direct study group. Obtained $t_{\text {count }} 2.45496$ from the data presented in the initial and final examinations, greater than $t_{\text {table }}$ of 1.77093 , the null hypothesis is rejected in this calculation. It can be said that there is a positive impact of the application of the direct learning model during discus throwing. The increase in learning outcomes for throwing discus with the direct learning model was $16.02 \%$. It is proven that the direct learning model's application has positive results on the learning outcomes of discus throwing. This result is in line with the statement of Sofan and Khoiru (2010) on structured procedural and declarative knowledge that can be developed in each student by applying direct learning models during learning. It is strengthened by Abduh's research (2016) to improve volleyball learning outcomes in under- passing subject matter, which can be done by implementing a direct learning model.

The difference scores from the final test in the inquiry learning model and the direct learning model. This is necessary to determine how far the better of the two learning models presented is towards the final results of student learning in discus throwing subject matter. Obtained $t$-value 2.023765 from the results of the ttest in the inquiry and direct study groups in the final test of physical education learning discus throwing subject matter, more excellent than $t$ table of 1.70113, the null hypothesis is rejected in this calculation. There is a difference between applying the inquiry learning model and direct learning based on the students' final test results on the discus throwing subject matter.

The value of the increase in the inquiry learning model group was better than the direct learning model application; it can be seen from the previous calculations, which obtained $25.78 \%$, compared to the explicit learning model of $16.02 \%$. The proposed hypothesis's truth can be proven; namely, the inquiry learning model is better than explicit learning. In a different study by Suprapto (2015), which also involved the direct learning model as a research variable, it was concluded that the natural learning model's application was no better than the contextual model and achievement motivation on cognitive learning outcomes.

In this study's results, the Inquire I model has a higher value than the direct learning model on discus throwing learning outcomes. In the statistical calculation, the learning model inquiry better than the direct learning model. Some things allow the model to search better than the direct learning model in the successful implementation of learning discus throwing. One of them is self-confidence. The inquiry I learning model provides an opportunity for students to find solutions to their problems. The teacher's attitude gives students the chance to explore themselves, resolving the issues to give men the confidence to find the expected answer. This is by the research of Prasojo, Mudian, and Haris (2015) that the inquiry learning model has a more significant effect on student self-confidence than the direct learning model. The self-confidence formed has a substantial opportunity for students to carry out the discus disc learning process

successfully.

The teacher's role in giving students the flexibility to seek and find their answers to something being questioned can also increase students' self-confidence. Of course, self-confidence will lead to a relaxed and 
active attitude. This is in line with Mujiburrohman (2018) research results, which state that the Inquire I learning model can make students seem more relaxed, more active, and able to find concepts well and deeply. Relaxing and being active are students 'attitudes, which indicate that students' interest in learning is an essential factor in the learning process, especially physical education learning. This is also consistent with the results presented by Darmawan (2018) that the students' motivation in learning to follow the Education coat seminal determined from aspects of the school environment, the role of teacher, and student interest.

\section{CONCLUSION}

After conducting research and processing the discus learning test results, the two learning models positively impacted student learning progress. The learning outcomes of the class IX students of SMP Negeri 3 Pekanbaru in the 2019/2020 academic year was showed that the implementation of inquiry learning was better than the direct learning model, with evidence of an increase in the percentage of student learning outcomes on the final test of disc throwing subject matter. However, to get better research results, this research needs to be done again with a larger sample and areas with similar problems as in this study.

\section{REFERENCES}

Abduh, I. (2016). Peningkatan Pembelajaran Passing Bawah Dalam Permainan Bola Voli Melalui Model Pembelajaran Langsung (Direct Instructions) Pada Siswa Kelas V SDN No 1 Pesaku Kecamatan Dolo Barat Kabupaten Sigi. Tadulako Journal Sport Sciences and Physical Education, 4(1), 1-15.

Ajepri, F. (2016). Kepemimpinan efektif dalam manajemen berbasis sekolah. AL-IDARAH: Jurnal Kependidikan Islam, 6(1), 132-167. https://doi.org/10.24042/alidarah.v6i1.793

Aji, G. S. B., Soegiyanto, \& Rahayu, S. (2015). Analisis Biomekanika Keterampilan Gerak Lempar Cakram Pada Atlet Berprestasi POPDA Jawa Tengah Tahun 2013. Journal of Sport Science and Fitness, 4(3), 10-15. https://doi.org/10.20884/1.jks.2013.8.2.

Annas, A. N. (2017). Manajemen Peserta Didik Berbasis Kecerdasan Spiritual Pendidikan Islam. TADBIR: Jurnal Manajemen Pendidikan Islam, 5(2), 132-142.

Darmawan, S. (2018). Pengaruh lingkungan sekolah, peran guru dan minat belajar siswa terhadap motivasi belajar penjas SD Inpres Buttatianang I Makassar. Jurnal Muara Pendidikan, 3(2), 103-111.

Fitrianii, F. (2016). Meningkatkan Kemampuan Lempar Tangkap Dalam Permainan Bola Kasti Melalui Model Pembelajaran Inkuiri Pada Siswa Kelas IV SDN Bobo Kecamatan Palolo. Tadulako Journal Sport Sciences and Physical Education, 4(1), 1-14.

Gustiawati, R., Fahrudin, F., \& Stafei, M. M. (2015). Implementasi Model-Model Pembelajaran Penjas Dalam Meningkatkan Kemampuan Guru Memilih dan Mengembangkan Strategi Pembelajaran Penjasorkes. Majalah Ilmiah SOLUSI, 1(03), 103-111.

Jarver, J. (2014). Belajar dan Berlatih Atletik. Bandung: Pionir Jaya.

Juliantine, T. (2009). Implementasi Model Inkuiri dalam Pembelajaran Pendidikan Jasmani. Bandung: FPOK Universitas Pendidikan Indonesia.

Kurniawan, D. (2014). Pengaruh Modifikasi Permainan Bolavoli Terhadap Kerjasama Siswa Pada Pembelajaran Pendidikan Jasmani, Olahraga dan Kesehatan (Studi Pada Siswa Kelas X Boga 1 SMKN 3 Probolinggo). Jurnal Pendidikan Olahraga dan Kesehatan, 3(1), 20-24. 
Mujiburrohman, J. (2018). Implementasi Model Pembelajaran Inquiry Untuk Meningkatkan Prestasi Belajar Penjasorkes Pada Permainan Bola Basket Siswa Kelas Xii. Mia 2 Di Man Subang Tahun Pelajaran 2015/2016. Jurnal Pendidikan Guru FKIP Universitas Subang, 1(2), 229-239.

Nelson, J. K., \& Thomas, J. R. (1990). Introduction to Research in Health, Physical Education, Recreation and Dance, Illinois. United States: Human Kinetics.

Novion, Z. (2018). Implementasi Model Pembelajaran Kooperatif Tipe Teams Games Tournament (TGT) Untuk Meningkatkan Hasil Belajar Siswa Pada Materi Menganalisis Teknik Dasar Passing Dalam Permainan Sepak Bola. Journal Sport Area, 3(1), 87-93. https://doi.org/10.25299/sportarea.2018.vol3(1).1412

Prasojo, W. A., Mudian, D., \& Haris, I. N. (2015). Pengaruh Model Pembelajaran Inkuiri Terhadap Peningkatan Rasa Percaya Diri Siswa Kelas XI Dalam Mata Pelajaran Pendidikan Jasmani Olahraga dan Kesehatan di SMK Negeri 2 Subang. BIOMARTIKA Jurnal Ilmiah FKIP Universitas Subang, $4(2), 81-88$.

Sinulingga, A. R. (2018). Peningkatan Hasil Belajar Lempar Cakram SMK Negeri 1 Pantai Cermin Kelas XI Melalui Evaluasi Proses Menggunakan Audio Visual. Jurnal Olahraga Rekreasi Samudra, 1(1), 1-8.

Sinulingga, A. R., \& Nova, A. (2018). Pengaruh Model Pembelajaran Dan Motivasi Terhadap Hasil Belajar Lompat Jauh (Studi Eksperimen pada Siswa kelas VII SMP Swasta Tarbiyah Islamiyah Hamparan Perak). Jurnal Olahraga Rekreasi Samudra, 1(1), 34-44

Sofan, A., \& Lif Khoiru, A. (2010). Proses Belajar Kreatif dan Inovatif dalam Kelas: Metode, Landasan Teoritis-Praktis dan Penerapannya. Jakarta: Prestasi Jakarta Publisher.

Sudayana, R. (2015). Statistika Penelitian Pendidikan. Bandung: Alfabeta.

Sudrajat, A. (2011). Mengapa pendidikan karakter? Jurnal Pendidikan Karakter, 1(1), 47-58.

Suprapto, E. (2015). Pengaruh model pembelajaran kontekstual, pembelajaran langsung dan motivasi berprestasi terhadap hasil belajar kognitif. Innovation of Vocational Technology Education, 11(1), 23-40. https://doi.org/10.17509/invotec.v11i1.4836

Wahyuni, U. (2015). Peran Guru Dalam Membentuk Karakter Siswa di SDN Jigudan Triharjo Pandak Bantul Tahun Pelajaran 2014/2015. Thesis. Universitas PGRI Yogyakarta. 